\title{
« Le minaret de Jam ». Paris - Kaboul. Expédition scientifique et culturelle sur la route de la soie, Paris, Hoëbeke, 2004, pp. 71-83.
}

\section{Audrey Peli}

\section{(2) OpenEdition} Journals

Édition électronique

URL : http://journals.openedition.org/abstractairanica/11542

DOI : 10.4000/abstractairanica. 11542

ISSN : 1961-960X

Éditeur :

CNRS (UMR 7528 Mondes iraniens et indiens), Éditions de l'IFRI

\section{Édition imprimée}

Date de publication : 15 mai 2007

ISSN : 0240-8910

\section{Référence électronique}

Audrey Peli, « « Le minaret de Jam ». Paris - Kaboul. Expédition scientifique et culturelle sur la route de la soie, Paris, Hoëbeke, 2004, pp. 71-83. », Abstracta Iranica [En ligne], Volume 28 | 2007, document 229, mis en ligne le 18 septembre 2007, consulté le 25 septembre 2020. URL : http://

journals.openedition.org/abstractairanica/11542 ; DOI : https://doi.org/10.4000/abstractairanica. 11542

Ce document a été généré automatiquement le 25 septembre 2020.

Tous droits réservés 


\section{«Le minaret de Jam ». Paris - Kaboul. Expédition scientifique et culturelle sur la route de la soie, Paris, Hoëbeke, 2004, pp. 71-83.}

\section{Audrey Peli}

Cette excursion en Afghanistan permit à ceux qui y participèrent de passer deux à trois jours au pied de ce minaret (570/1175) dont la perfection architecturale et décorative tout autant que la présence, dans ce confluent cerné de montagnes, restent difficiles à comprendre. Pour certains cet environnement exigu rend impossible l'identification de Jām avec Fīrūzkūh, la capitale dynastique des Ghurides. Pourtant deux sources narratives s'accordent parfaitement pour désigner le site du minaret de Jām comme Fīrūzkūh: l'une est la "Géographie de Ḥāfez-e Abrū » (XVs.), l'autre les Ṭabaqāt-e Nāṣerī, chronique contemporaine de la dynastie des Ghurides. Cette dernière donne des précisions topographiques concernant des évènements survenus à Fīrūzkūh qui s'accordent tellement à la configuration de Jām qu'il est impossible de dissocier ces deux sites. L'article donne d'autres détails, archéologiques et épigraphiques confortant cette identification.

\section{INDEX}

Thèmes : 5.1. Monde iranophone 
AUTEURS

AUDREY PELI

Paris 